\title{
Review of the tribe Lyropaeini (Coleoptera: Lycidae)
}

\author{
Milada BOCÁKOVÁ \\ Department of Biology, Pedagogical Faculty, Palacký University, Purkrabská 2, CZ-771 40 Olomouc, Czech Republic; \\ e-mail: mbocakova@lycos.com
}

Key words. Taxonomy, new species, key, neoteny, Oriental and Australian Region

\begin{abstract}
A review of genera within the tribe Lyropaeini is given. Three new genera - Lyrolib gen. n., Horakiella gen. n., and Ambangia gen. n., and a subgenus Macroambangia subgen. n. within Ambangia gen. n. are described. The following twelve new species are proposed as new to science: Ambangia nigra sp. n. (Sulawesi), A. wallacei sp. n. (Sulawesi), Ambangia (Macroambangia) pallidicornis sp. n. (Sulawesi), A. (M.) celebensis sp. n. (Sulawesi), A. (M.) nigricornis sp. n. (Sulawesi), Alyculus wittmeri sp. n. (Sumatra), Horakiella hammondi sp. n. (Malaysia: Sarawak), H. pahangana sp. n. (Peninsular Malaysia), $H$. emasensis sp. n. (Malaysia: Sabah), Lyrolib minor sp. n. (Sulawesi), L. grandis sp. n. (Sulawesi), and Microlyropaeus dembickyi sp. n. (Sumatra). A key to genera of Lyropaeini is given, and comments on their relationships are provided.
\end{abstract}

\section{INTRODUCTION}

The Lyropaeini Bocák \& Bocáková, 1989 was described as a monotypic tribe consisting of the genus Lyropaeus Waterhouse, 1878. Within the last decades several other Lyropaeini genera were proposed (Bocáková \& Bocák, 1999; Kazantsev, 1998, 1999; Bocák, 2002). Subdihammatus and Microlyropaeus were recently considered members of Leptolycinae (Bocáková, 2001, 2004) close to the genus Lyropaeus. Currently Lyropaeini includes nine described genera with Oriental and partly Australian (Lombok, Sulawesi) distribution.

The genera of Lyropaeini are largely monotypic, or contain few species, with the exception of remarkable Lyropaeus with about 25 described species. Species range in size from less than $3 \mathrm{~mm}$ to $12 \mathrm{~mm}$. Lyropaeini colour patterns are simple, usually orange or black. The knowledge of Lyropaeini preimaginal stages is poor, only the larva of Lyropaeus was described by Gravely (1915).

One of the most interesting phenomena within the superfamily Elateroidea is the varying degree of neoteny that can be found in females of former Cantharoidea. A generally well known example within lycids are the "trilobite" larviform females of Duliticola Mjöberg, 1925 (Bocák \& Matsuda, 2003) who do not undergo pupation and are paedomorphic. Among lycids there are several other genera known only from males like Dexoris Waterhouse, 1878, Lyropaeus Waterhouse, 1878, Scarelus Waterhouse, 1878, Leptolycus Leng \& Mutchler, 1922, Eurrhacus Waterhouse, 1879 etc. Lyropaeini females have not been found yet, and therefore they are also probably wingless or neotenic, or perhaps paedomorphic. The relationships of these taxa are rather obscure. Their morphology offers several common characters but most of them can be designated as reductions, and therefore are suspicious of homoplasious origin. On the other hand these genera have many striking autapomorphic features. This makes them easily distinguishable from other lycids but makes their relatedness to other groups unclear based on morphological characters only. Therefore, the question whether neoteny evolved only once or several times within lycids has not been resolved yet, and it is necessary to investigate the evidence using other methods, e.g. molecular characters. Multiple origins of neotenous groups of lycids is more probable, similarly as in Elateroidea. Clearly, a revision of our knowledge of Lyropaeini is needed, and the present paper is an attempt to implement it, providing also a key to all genera, including those newly proposed herein. The relationships of Lyropaeini to other neotenous lycid groups are the subject of a forthcoming paper.

\section{MATERIAL AND METHODS}

The material for this paper was largely collected under the Wallace Project in 1985 in northern Sulawesi (Knight, 1988), organised by the Royal Entomological Society of London. These specimens were loaned from The Natural History Museum in London through the courtesy of M. Brendell and M. Kerley. Specimens were examined using an Olympus SZX 12 stereoscopic microscope, with magnification up to $90 \times$, and were illustrated using digital photographs taken with an Olympus Camedia 3000 digital camera.

All measurements are in $\mathrm{mm}$. Somatic morphology measurements were taken using an ocular micrometer. Eye diameter and interocular distances are taken from the span of eyes. When the eye outline was not circular the diameter was measured at the widest point, the interocular distances at the narrowest point. The body width was measured at humeri in dorsal view. Male genitalia were dissected after having been boiled in $10 \% \mathrm{KOH}$ solution. Wing venation terminology follows Kukalova-Peck \& Lawrence (1993).

\section{DEPOSITORIES}

BMNH - The Natural History Museum, London (M. Kerley)

LMBC - author's collection

NMPC - The National Museum, Praha, Czech Republic (V. Švihla)

ZMPA - Zoological Institute of the Polish Academy of Sciences, Warszawa, Poland (T. Huflejt) 


\section{Tribe Lyropaeini Bocák \& Bocáková, 1989}

Lyropaeini Bocák \& Bocáková, 1989: 718, type genus: Lyropaeus Waterhouse, 1878.

Paralycinae Medvedev \& Kazantsev, 1992: 55, type genus: Paralycus Medvedev \& Kazantsev, 1992.

Diagnosis. Head small, eye diameter smaller than distance between eyes. Mouth vertical, often reduced. Maxillary palpi 4-segmented, terminal palpomere apically pointed, galea present, lacinia obsolete. Labium strongly reduced, labial palpi 1-3 segmented, terminal palpomere apically pointed. Antennae 10-11 segmented. Pronotum usually trapezoidal, without carinae, sometimes with median longitudinal groove posteriorly, posterior angles of pronotum projected obliquely backwards. Scutellum small, deeply emarginate apically. Each elytron with 4-9 weak longitudinal costae, costae sometimes indistinct. Intercostal intervals with irregular reticulate cells or punctures, sometimes elytra almost glabrous. Male genitalia trilobed, phallobase always present, sometimes fused to paramerae. Paramerae usually apically pointed, with sharp ventrobasal projection (Figs 39, 44 etc.). Females unknown.

Composition. As here understood, Lyropaeini contain nine described genera (Lyropaeus, Lybnopaeus, Lyroneces, Skrivania, Subdihammatus, Antennolycus, Microlyropaeus, Pendola, Alyculus), and three genera newly proposed herein.

Distribution. Oriental Region; Lombok, Sulawesi.

\section{KEY TO GENERA OF LYROPAEINI}

1 Antennae 10-segmented. . . . . . . . . . . . . . . . 2

- Antennae 11-segmented. . . . . . . . . . . . . . . . . . . 4

2 Paramerae coalescent with phallobase. Lyroneces Kazantsev

- Paramerae and phallobase separate. ............... 3

3 Male genitalia with median lobus dorsoventrally flattened... Lyropaeus Waterhouse Male genitalia with median lobus laterally flattened. ....... ......................... Lybnopaeus Kazantsev

4 Elytra strongly shortened, as long as half of body length.... ............................... Alyculus Kazantsev

Elytra entirely covering the abdomen. . . . . . . . . . 5

5 Antennomere 3 long, as long as $4 \ldots . . \ldots$. Lyrolib gen. $n$.

- Antennomere 3 short, about as long as $2 \ldots \ldots \ldots \ldots 6$

6 Antennomeres 4-11 with tumbler-shaped subsegments. ..... ................... Antennolycus Bocák \& Bocáková

- All antennomeres simple. . . . . . . . . . . . . . . 7

7 Male genitalia with paramerae as long as one third of phallus, recurrent apically (Fig. 44)........ Microlyropaeus Pic

- Paramerae almost straight in apical portion. ......... 8

8 Paramerae as long as phallus, with dorsal margin bent ventrally........................... 9

- Paramerae at least $1 / 6$ shorter than phallus. ......... 10

9 Both phallus and paramerae arcuately bent ventrally........ ...................... Skrivania Bocák \& Bocáková - Phallus and paramerae arcuately bent to opposite directions, phallus bent ventrally, paramerae dorsally. ........... ....................... Subdihammatus Kleine

10 Paramerae short, as long as half of phallus, distally stout and toothed, phallus apically pointed.......... Pendola Bocák

- Paramerae largely longer than half of phallus, if paramerae short, then phallus apically rounded. . . . . . . . . 11
11 Phallus apically rounded, phallobase short, as long as one quarter of phallus (Figs 45-53)........ Horakiella gen. n. Phallobase long, usually as long as half of phallus (Figs 31-43). . . . . . . . . . . . . . . . . . Ambangia gen. n.

\section{Genus Lyropaeus Waterhouse, 1878}

Lyropaeus Waterhouse, 1878: 105, type species Lycus fallax Walker, 1858 (by monotypy).

Paralycus Medvedev \& Kazantsev, 1992: 55, type species Paralycus helvius Medvedev \& Kazantsev, 1992 (by monotypy) [synonymy by Kazantsev (1993)].

Diagnosis. Head small, largely hidden by pronotum, eyes hemispherically prominent. Antennae 10-segmented, laterally compressed. Mouthparts vertical, mandibles small, reduced, curved apically. Maxillary palpi 4-segmented, terminal palpomere small, apically pointed. Labium reduced, labial palpi 1-segmented, apically pointed. Pronotum trapezoidal, without carinae, scutellum considerably emarginate apically. Elytra flat, each elytron with four weak longitudinal costae, costa 3 almost invisible, intercostal intervals finely punctured, reticulate cells missing. Male genitalia trilobed, phallobase long, as long as aedeagus. Paramerae robust, provided with ventrobasal projection.

Composition. Lyropaeus includes more than 25 species.
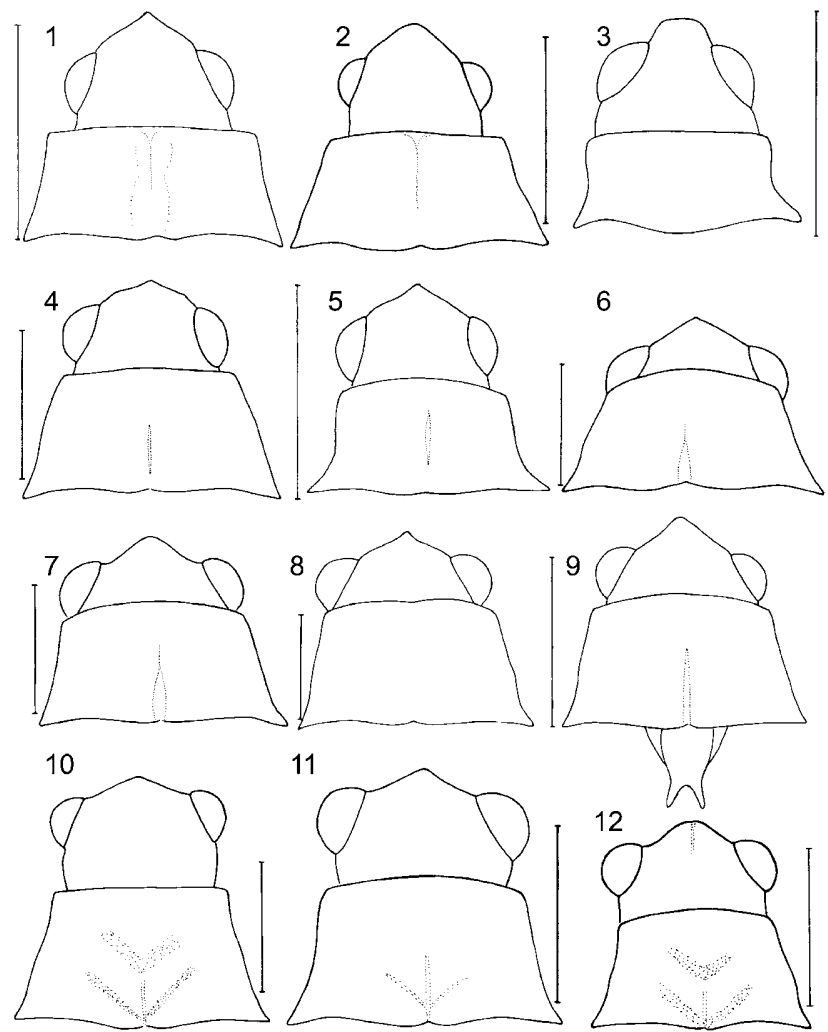

Figs 1-12: Head and pronotum of: 1 - Lyrolib minor sp. n., 2 - L. grandis sp. n., 3 - Alyculus wittmeri sp. n., 4 -Ambangia nigra sp. n., $5-A$. wallacei sp. n., $6-A$. (Macroambangia) pallidicornis sp. n., $7-A$. (M.) celebensis sp. n., $8-A$. (M.) nigricornis sp. n., 9 - Microlyropaeus dembickyi sp. n., $10-$ Horakiella hammondi sp. n., $11-H$. pahangana sp. n., $12-H$. emasensis sp. n. Scale $-0.5 \mathrm{~mm}$; scale for Fig 3: $0.25 \mathrm{~mm}$. 
Distribution. Widely distributed through Oriental Region (India, Ceylon, Nepal, Malaysia, Sumatra, Java, Borneo).

Type material. Lycus fallax Walker, holotype, o, "Ceylon" (BMNH)

\section{Genus Lybnopaeus Kazantsev, 1998}

Lybnopaeus Kazantsev, 1998: 16, type species: Lyropaeus avernus Kazantsev, 1997 (by monotypy).

Diagnosis. Head flat behind eyes, antennae 10segmented, mouthparts reduced, maxillary palpi slender and short, terminal palpomere apically pointed. Pronotum small, trapezoidal, scutellum elongate, conspicuously emarginate apically. Elytra widened posteriorly, each elytron with four weak longitudinal costae. Male genitalia trilobed, aedeagus and paramerae considerably flattened laterally.

Composition. Lybnopaeus is a monotypic genus.

Distribution. Borneo: Sabah.

Comments. Closely related to Lyropaeus, the only distinguishing characters of Lybnopaeus from Lyropaeus given by Kazantsev (1998) are: presence of suberect antennal pubescence, presence of glabrous grooves on antennomeres, and "differences in the structure of aedeagus". As these differences Kazantsev (1998) probably considered laterally flattened phallus in Lybnopaeus.

\section{Genus Lyroneces Kazantsev, 1998}

Lyroneces Kazantsev, 1998: 17, type species: Lyroneces orcinus Kazantsev, 1998 (by original designation).

Diagnosis. Head flat behind eyes, eyes small, antennae 10-segmented, flattened at base, filiform distally. Mouthparts reduced, maxillary palpi slender and short, terminal palpomere apically pointed. Pronotum small, trapezoidal, scutellum elongate, conspicuously emarginate apically. Elytra widened posteriorly, each elytron with four weak longitudinal costae, alternate costae stouter, legs flattened. Male genitalia with paramerae and phallobase coalescent.

Composition. Lyroneces includes eight species.

Distribution. Malaysia, Borneo, Assam.

Comments. Closely related to Lyropaeus from which it differs in the shape of male genitalia having paramerae coalescent with phallobase.

\section{Genus Skrivania Bocáková \& Bocák, 1999}

Skrivania Bocáková \& Bocák, 1999: 107, type species: Skrivania minuta Bocáková \& Bocák, 1999 (by original designation).

Diagnosis. Head large, only weakly inserted into pronotum. Eyes small, antennae 11-segmented, antennomeres 2 and 3 very small, antennomere 3 smaller than 2 . Maxillary and labial palpi small, their terminal palpomeres apically pointed. Pronotum trapezoidal, without carinae. Elytra much wider than pronotum, elytral costae weak, reticulate cells irregular. Male genitalia with paramerae almost as long as phallus, simple, curved dorsally, provided with ventrobasal projections.

Distribution. Peninsular Malaysia.
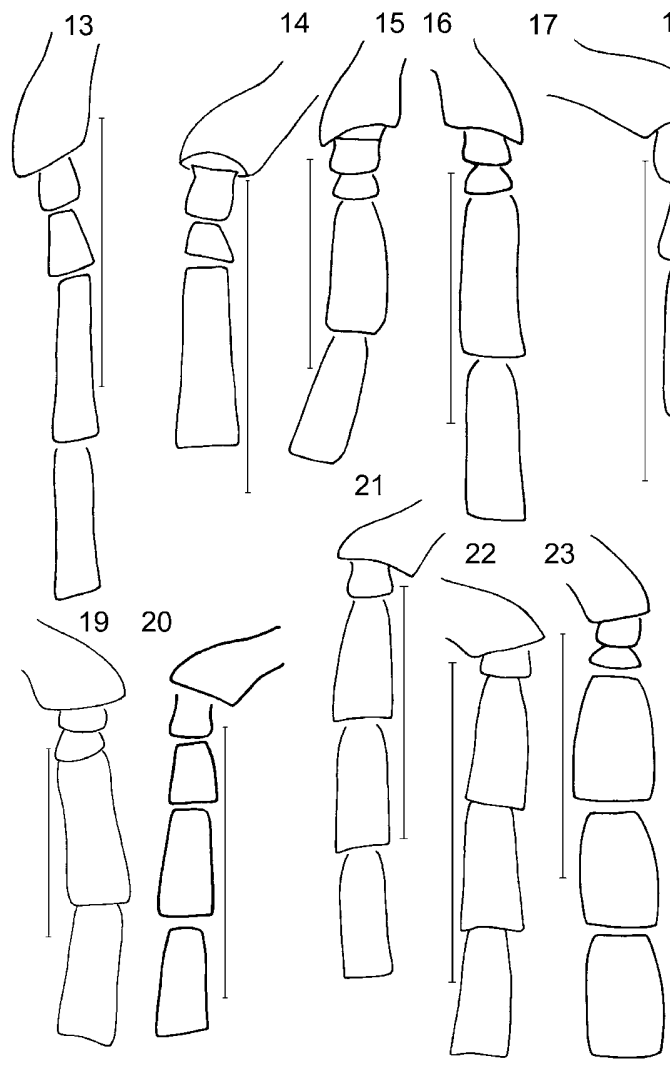

18

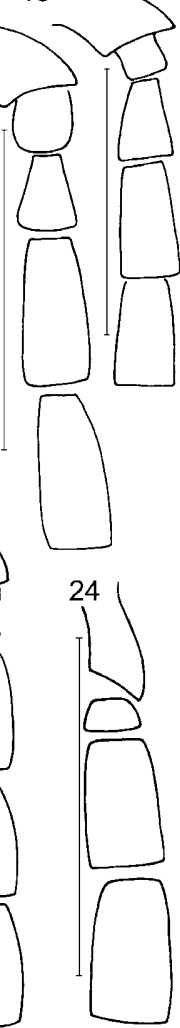

Figs 13-24: Basal antennomeres of: 13 - Horakiella hammondi sp. n., $14-H$. pahangana sp. n., 15 - Ambangia (Macroambangia) pallidicornis sp. n., $16-A$. (M.) celebensis sp. n., $17-A$. (s. str.) wallacei sp. n., $18-A$. (s. str.) nigra sp. n., $19-$ A. (M.) nigricornis sp. n., $20-$ Horakiella emasensis sp. n., 21Lyrolib grandis sp. n., 22 - L. minor sp. n., 23 - Microlyropaeus dembickyi sp. n., $24-$ Alyculus wittmeri sp. n. Scale $-0.5 \mathrm{~mm}$, scale for Figs 17-24: $0.25 \mathrm{~mm}$.

Type material. Skrivania minuta, holotype, đิ, Malaysia, Cameron Highlands, Tanah Rata, 19.-23. iii. 1998, 1600-1900 m, L. Bocák lgt. (LMBC).

\section{Genus Subdihammatus Kleine, 1926}

Subdihammatus Kleine, 1926: 68, type species: Subdihammatus curvus Kleine, 1926 (by monotypy).

Diagnosis. Head partly hidden by pronotum, eyes small, interocular distance almost twice as long as the span of the eye. Antennae filiform, reaching elytral midlength. Antennomere 1 stout, basally constricted, antennomeres 2 and 3 very small, 3 slightly longer than 2 . Antennomere four is the longest of all, slightly longer than 5. Terminal maxillary palpomere apically pointed. Pronotum trapezoidal, anterior margin weakly produced forwards. Scutellum small, deeply emarginate in apical third. Each elytron with four primary costae, secondary costae sometimes irregular to obliterate. Male genitalia with long, dorsally fused paramerae, phallus curved in opposite direction than paramerae, phallus bent ventrally, paramerae dorsally. Female unknown.

Distribution. Philippines: Luzon.

Comments. The genus was transferred to the subfamily Leptolycinae by Bocáková (2001) on the basis of the 
shape of male genitalia and reduced mouthparts. Although the holotype aedeagus is partly destroyed, Subdihammatus seems to be related to Skrivania Bocáková \& Bocák, 1999 from Malaysia.

Type material. Subdihammatus curvus, holotype, đo, "Luzon, Mt. Makiling, Baker" (ZMPA).

\section{Genus Antennolycus Bocáková \& Bocák, 1999}

Antennolycus Bocáková \& Bocák, 1999: 105, type species: Antennolycus constrictus Bocáková \& Bocák, 1999 (by original designation).

Diagnosis. Small and delicate lycid genus with very small antennomeres 2 and 3, antennomere 3 slightly shorter than 2, antennomeres 4-11 with tumbler-shaped subsegments. Male genitalia with strongly shortened paramerae, provided with spinose projections apically.

Distribution. Peninsular Malaysia.

Comments. The genus Antennolycus was described for the only species $A$. constrictus from Malaysia. The shape of antennomeres 4-11 (tumbler-shaped subsegments) seems to be distinctive within all Lycidae.

Type material. Antennolycus constrictus, holotype, ô, Malaysia, Cameron Highlands, Tanah Rata, 19.-23. iii. 1998, 1600-1900 m, L. Bocák lgt. (LMBC).

\section{Genus Microlyropaeus Pic, 1929}

(Figs 9, 23, 44, 73)

Microlyropaeus Pic, 1929: 4, type species: Microlyropaeus notaticollis Pic, 1929 (by monotypy).

Diagnosis. The distinctive features of the genus include the shape of phallus gradually widened basally, the shape of antennae with extremely small antennomeres 2 and 3, and robust antennomeres 4-10. It differs from Antennolycus in having simple filiform antennae, the structure of elytra, and the shape of aedeagus having phallus parallel-sided in basal $4 / 5$.

Distribution. Indonesia: Sumatra.

Remark. Microlyropaeus Pic seems to be related to Antennolycus Bocáková \& Bocák. These genera share many characters, especially the structure of aedeagus. DNA sequences of five genes (four mitochondrial - COI, $16 \mathrm{~S}$, cytB, ND5, and one nuclear - 18S) of Microlyropaeus dembickyi substantially differ from Antennolycus constrictus (in $20 \%$ of bases - unpubl. data), and therefore these genera are kept with generic rank.

\section{Microlyropaeus dembickyi sp. $\mathbf{n}$.}

(Figs 9, 23, 44, 73)

Diagnosis. It differs from $M$. notaticollis (yellow except discal part of pronotum and scutellum) in dark brown body colouration, and the shape of male genitalia, with phallus strongly constricted medially in M. notaticollis.

Description. Body dark brown, only basal region of elytra rather lighter. Head with small eyes, interocular distance $1.7 \times$ longer than eye diameter. Antennae filiform, reaching elytral midlength, antennomere 2 and 3 very small (Fig. 23), antennomere 3 slightly shorter than
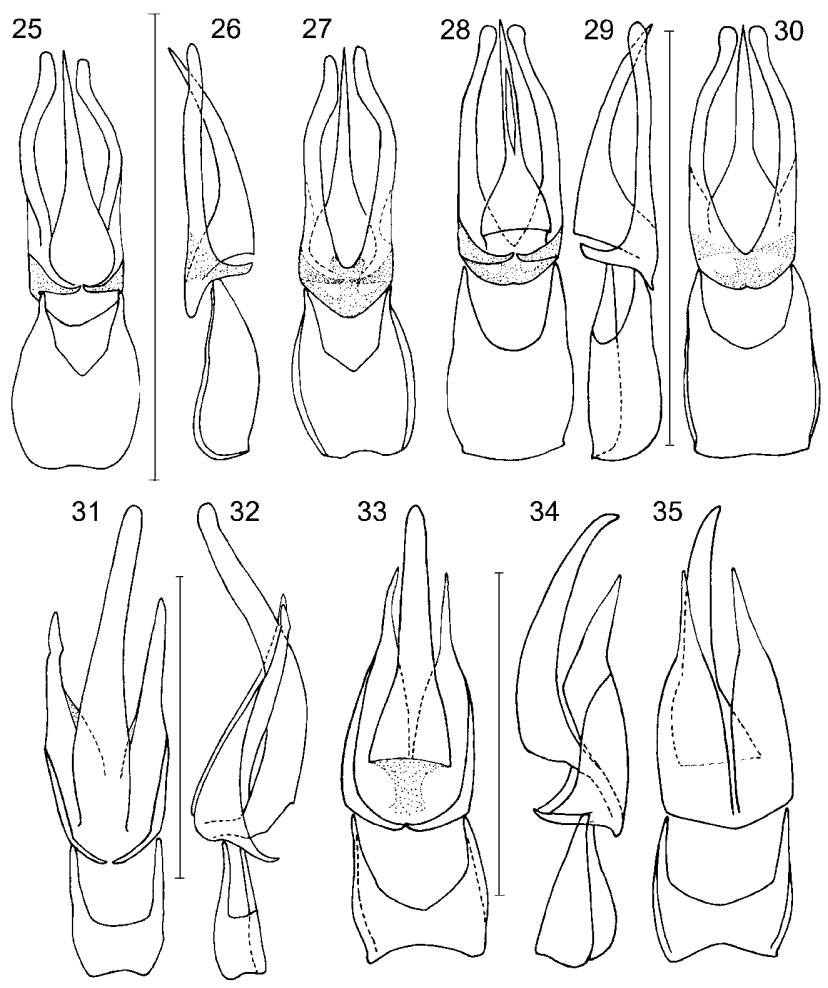

Figs 25-35: Male genitalia of: 25-27: Lyrolib minor sp. n., 28-30: L. grandis sp. n., 31-32: Ambangia nigra sp. n., 33-35: A. wallacei sp. n. Scale $-0.5 \mathrm{~mm}$; scale for Figs 33-35: 0.25 $\mathrm{mm}$.

2. Mouthparts inserted ventrally, terminal palpomeres of maxillary and labial palpi pointed distally. Pronotum trapezoidal, transverse, widest at basal margin, lateral margins almost straight. Pronotum with slender longitudinal groove in basal half. Scutellum bilobed in distal half, its posterior tips heading obliquely backwards. Elytra parallel-sided, 3.4× longer than humeral width. Each elytron with 9 weak, almost equally strong, longitudinal costae, intercostal intervals with irregular reticulate cells. Wing venation with brace $\mathrm{CuA}_{1}$ very weak, attached to $\mathrm{MP}_{3+4}$ at the point of its bifurcation. Abdominal sternum nine elongate, terminal tergum with slender emargination distally. Legs slender, elongate, trochanters long, tibiae straight, their spurs small, slender, only tarsomere 4 lobed. Male genitalia with phallus widest basally, lateral margins of phallus convergent distally. Paramerae short, as long as one third of phallus. Body length: $3.7 \mathrm{~mm}$, humeral width: $0.9 \mathrm{~mm}$.

Etymology. Named in honour of the collector, L. Dembický (Brno, Czech Republic).

Type material. Holotype, ơ, Sumatra, Jambi prov., Kerinci, Seblat N.P., $7 \mathrm{~km} \mathrm{E} \mathrm{Kayuaro,} \mathrm{Mt} \mathrm{Tujuh,} \mathrm{25.ii.-2.iii.2003,}$ $1^{\circ} 45^{\prime} \mathrm{S} 101^{\circ} 25^{\prime} \mathrm{E}, 1750 \pm 250 \mathrm{~m}$, L. Dembický leg. (LMBC).

Distribution. Indonesia: Sumatra.

\section{Genus Pendola Bocák, 2002}

Pendola Bocák, 2002: 557, type species: Pendola flava Bocák, 2002 (by original designation).

Diagnosis. Slender lycid genus with 11-segmented antennae, and very small antennomeres 2 and 3, antenno- 
mere 3 slightly shorter than 2 . Pronotum without carinae, elytra with distinct elytral costae, intercostal intervals with two rows of irregular reticulate cells. Male genitalia with strongly shortened paramerae reaching middle of aedeagus length, with spinose ventrobasal projections, phallus apically pointed.

Distribution. Indonesia: Lombok, Sulawesi.

Comments. On the basis of the shape of male genitalia Pendola seems to be closely related to Lyropaeus from which it differs in 11-segmented antennae. Currently known distribution of Pendola is restricted to westernmost islands of Australian Region.

Type material. Pendola flava, holotype, ô, C Sulawesi, 38 km SE Pendolo vill. (pass), $2^{\circ} 14^{\prime} 03^{\prime \prime S}, 120^{\circ} 46^{\prime} 5^{\prime \prime} \mathrm{E}, 17 . v i i .1999$, $1200 \mathrm{~m}$, Bolm lgt. (LMBC).

\section{Genus Lyrolib gen. n.}

(Figs 1-2, 21-22, 25-30, 56, 59-64)

Type species. Lyrolib minor sp. $\mathrm{n}$.

Diagnosis. Lyrolib gen. n. differs from most other Lyropaeini genera in having 11-segmented antennae with only antennomere 2 small, and in the shape of male genitalia with curved distal portion of paramerae.

Description. Head with medium sized eyes, interocular distance slightly longer than eye diameter, antennae filiform, 11-segmented. Antennomere 1 stout, 2 very small, 3-11 almost equally long, antennomere 3 about 4-6× longer than 2 (Figs 21-22). Mouthparts reduced, labrum small, transverse, laterally tapering at apex. Maxillary palpi 4-segmented, labial palpi 3-segmented, terminal palpomeres of both palpi strongly pointed apically. Pronotum considerably transverse (Figs 1-2), trapezoidal, lateral margins weakly emarginate, with slight, median longitudinal carina in anterior two-thirds. Scutellum oblong, slightly apically emarginate. Anterior thoracic spiracles inconspicuous. Elytra elongate, parallel-sided, about $3 \times$ longer than humeral width.

Each elytron with nine very slight longitudinal costae, primary costae (i.e. costae $2,4,6,8$ ) weakly strengthened, alternate costae 1, 3, 5, 7, 9 strongly diminishing in posterior half, costae 1 and 3 missing in posterior half. Reticulate cells irregular. Prosternum trapezoidal, mesosternum transverse. Wing venation with brace $\mathrm{CuA} 1$ absent, wing jugal region strongly reduced (Fig. 56). Terminal abdominal sternum elongate, lateral margins strengthened, emarginate medially, terminal tergum apically emarginate. Legs rather slender, trochanters long. Male genitalia with phallus apically pointed, curved dorsoventrally, paramerae as long as phallus, rounded distally, curved inwards laterally in distal third. Ventrobasal projection of paramerae transverse, phallobase rather flattened. Female unknown. Body length: 2.7-3.6 mm.

Etymology. Name Lyrolib is derived from other lycid generic names Lyropaeus and Libnetis. The gender is masculine.

Distribution. Indonesia: Sulawesi.

\section{Lyrolib minor sp. $\mathbf{n}$.}

(Figs 1, 22, 25-27, 56, 63)
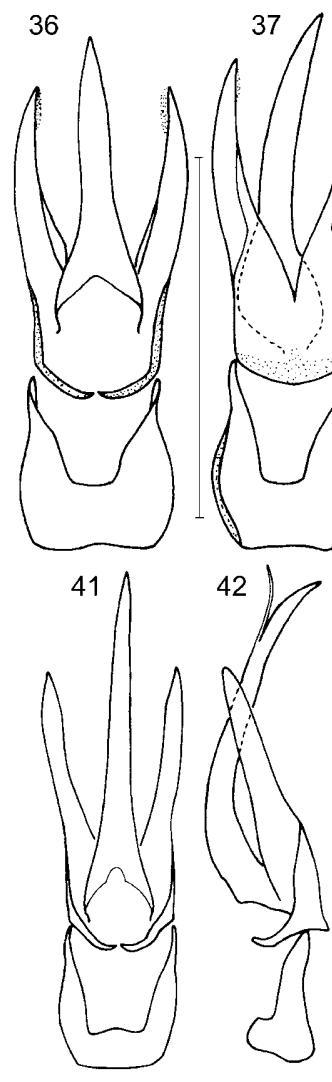
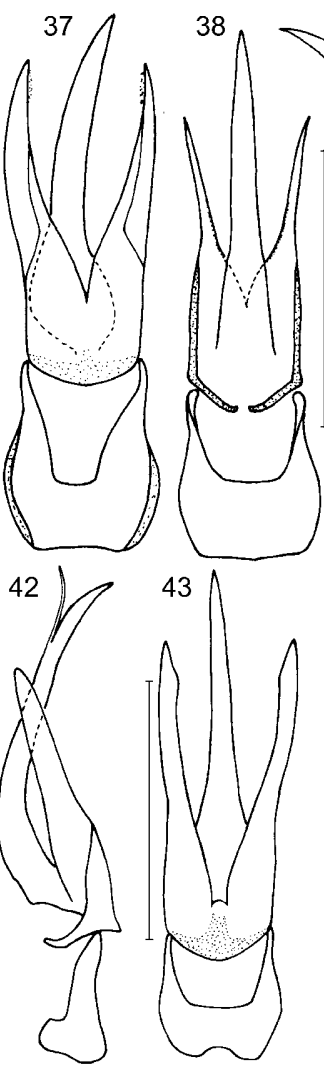
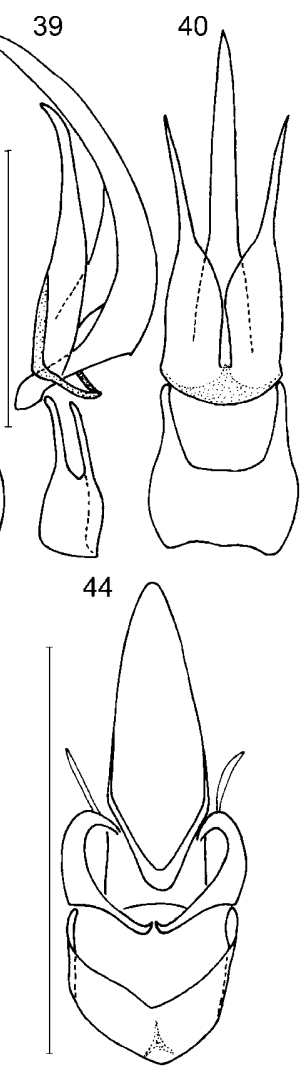

Figs 36-44: Male genitalia of: 36-37: Ambangia (Macroambangia) pallidicornis sp. n., 38-40: A. (M.) celebensis sp. n., 41-43: A. (M.) nigricornis sp. n., 44 - Microlyropaeus dembickyi sp. n. Scale $-0.5 \mathrm{~mm}$.

Diagnosis. Lyrolib minor differs from the following species in having apical portion of paramerae parallel.

Description. Body dark brown, only antennomere 11 yellow. Head with medium-sized eyes, interocular distance $1.5 \times$ longer than eye diameter, antennae filiform (Fig. 22), reaching elytral midlength, circular in crosssection.

Mandibles strongly reduced, labrum rounded apically. Maxillary and labial palpi with terminal palpomeres apically pointed. Pronotum trapezoidal, strongly transverse, widest at base, posterior angles acute, with weak median longitudinal carina in anterior two-thirds, which is placed in small longitudinal groove (Fig. 1). Scutellum with shallow arcuate apical notch. Elytra elongate, subparallelsided, about $3 \times$ longer than humeral width. Each elytron with nine very weak longitudinal costae, alternate costae strengthened. Reticulate cells irregular, diminishing in distal half. Abdominal sternum 9 elongate, tergum 9 emarginate apically. Legs small, compressed, trochanters slightly elongate. Male genitalia with phallus widened basally, apex acute, paramerae parallel in distal portion. Body length: $2.7-2.9 \mathrm{~mm}$, humeral width: $0.7-0.8 \mathrm{~mm}$.

Etymology. Named in reference to body size.

Type material. Holotype, đิ, Indonesia, Sulawesi Utara, Dumoga Bone N.P., March 1985 (BMNH). Paratypes: the same

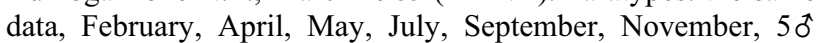
(BMNH), 20 (LMBC). 
Biology. Specimens were collected using flight interception traps (6) and Malaise traps (2).

Distribution. Indonesia: Sulawesi.

\section{Lyrolib grandis sp. $\mathbf{n}$.}

(Figs 2, 21, 28-30, 59-62, 64)

Diagnosis. Lyrolib grandis differs from closely related L. minor in having bulb-shaped apical portion of paramerae, flattened antennae, and larger body size.

Description. Body dark brown, only antennomere 11 usually yellow (sometimes only in its apical portion).

Head with small eyes, interocular distance $1.5 \times$ longer than eye diameter, antennae filiform, rather flattened, reaching elytral midlength. Mandibles short, slightly arcuate, labrum small, rounded apically. Maxillary palpi short, 4-segmented, terminal palpomeres of maxillary and labial palpi apically pointed. Pronotum widest at base, anterior margin slightly produced forwards, sides elevated. Anterior two-thirds of pronotum with small median longitudinal carina, median groove absent. Scutellum with a shallow apical notch. Elytra elongate, subparallel-sided, $3.2 \times$ longer than humeral width. Each elytron with nine longitudinal costae, costae 1, 2, and 3 diminishing in posterior half. Reticulate cells irregular. Male sternum 9 elongate, terminal abdominal tergum emarginate apically. Legs slender, compressed, trochanters elongate, tibiae straight. Male genitalia with phallus broad basally, paramerae apically rounded, bulb-shaped. Body length: 3.4-3.6 mm, humeral width: 0.9-1.0 $\mathrm{mm}$.

Etymology. Named in reference to body size.

Type material. Holotype, $\widehat{\sigma}$, Indonesia, Sulawesi Utara, Gng. Ambang E.R., nr. Kotamobagu, Gn. Muajat summit, 1760 m, 18-24 May 1985 (BMNH). Paratypes: the same data, lower

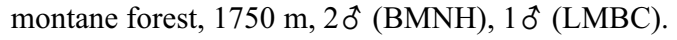

Biology. Specimens were collected using yellow pan traps.

Distribution. Indonesia: Sulawesi.

\section{Genus Ambangia gen. n.}

(Figs 4-8, 15-19, 31-43, 65-67, 71-72)

Type species. Ambangia nigra sp. $\mathrm{n}$.

Diagnosis. Ambangia is related to Pendola Bocák, 2002 from which it differs in having rounded apex of phallus, membranous distal portion of paramerae, longer antennomere 3, and strongly irregular reticulate cells.

Description. Head with small eyes, interocular distance 1.4-1.7× longer than eye diameter, antennal tubercles strongly elevated. Antennae filiform (Figs 15-19), circular in cross-section, antennomere 1 stout, 2 small, 3 as long as 2 or at most, twice longer than 2. Antennomeres 4-10 about $2-5 \times$ longer than 3 , antennomere 11 slightly longer than 10 .

Mouthparts reduced, mandibles arcuate, labrum rounded distally, maxillary palpi 4-segmented, terminal palpomere of maxillary and labial palpi strongly pointed at apex. Pronotum transverse, trapezoidal, provided with a weak median longitudinal groove, lateral margins simply emarginate. Scutellum oblong with a shallow

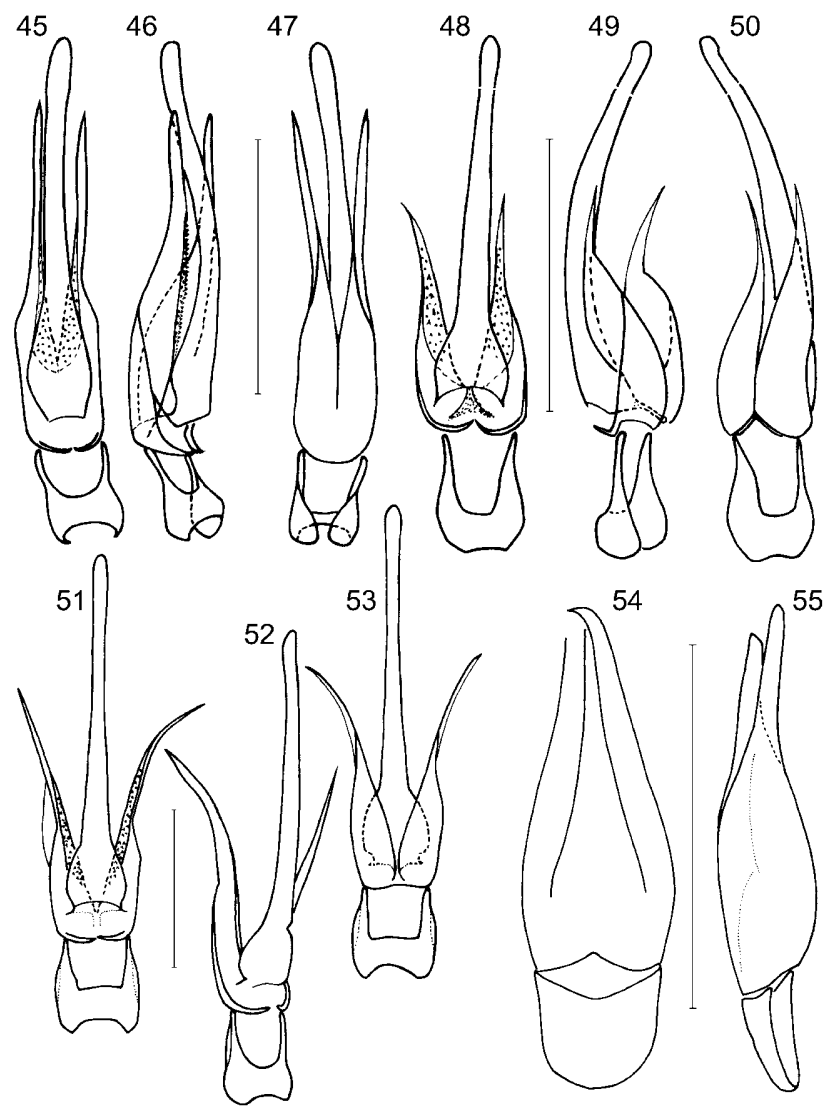

Figs 45-55: Male genitalia of: 45-47: Horakiella pahangana sp. n., 48-50: H. emasensis sp. n., 51-53: H. hammondi sp. n., 54-55: Alyculus wittmeri sp. n. Scale $-0.5 \mathrm{~mm}$, scale for Figs 54-55: $0.125 \mathrm{~mm}$.

arcuate apical notch. Anterior thoracic spiracles reduced. Elytra elongate, parallel-sided, over $3 \times$ longer than width at humeri. Each elytron with nine slight costae, alternate costae rather stronger, intercostal intervals with irregular reticulate cells. Wing venation with brace $\mathrm{CuA}_{1}$ almost invisible, very slight, shifted to base of $\mathrm{MP}_{3+4}$. Terminal abdominal sternum laterally emarginate, terminal abdominal tergum slightly emarginate apically. Legs slender, trochanters long. Male genitalia with stout paramerae, distal half of paramerae narrowed, phallus apically rounded, dorsoventrally flattened. Phallobase attached to paramerae by long projections. Body length: 2-5 mm. Females unknown.

Etymology. The name Ambangia is derived from locality datum of the holotype - Mt. Ambang. The gender is feminine.

Distribution. Indonesia: Sulawesi.

\section{Ambangia nigra sp. $\mathbf{n}$.}

(Figs 4, 18, 31-32, 71)

Diagnosis. Secondary costae present in whole elytral length, phallus narrowed proximally. Ambangia nigra differs from the following species in having a larger bodysize, in the shape of the aedeagus, and in the fully developed secondary elytral costae.

Description. Body entirely black. Head with small eyes, interocular distance $1.7 \times$ longer than eye diameter. 
Antennae filiform, reaching over basal elytral third, antennomere 1 stout, 2 small, 3 about twice longer than 2 . Mandibles arcuate, labrum rounded distally. Maxillary palpi 4-segmented, labial palpi strongly reduced, terminal palpomeres of both palpi apically pointed. Pronotum widest at basal margin (Fig. 4), slightly produced forwards, median portion with weak median longitudinal groove, posterior angles acute. Elytra subparallel-sided, $3.5 \times$ longer than humeral width. Abdominal sternum 9 elongate, with an aperture in proximal half. Legs slender, trochanters as long as third of femur. Male genitalia with phallus slightly narrowed basally, widest in basal third, apex widely rounded. Body length: $4.5-5.1 \mathrm{~mm}$, width at humeri: $1.1-1.3 \mathrm{~mm}$.

Etymology. Named in reference to body colouration.

Type material. Holotype, $\hat{\sigma}$, Indonesia, Sulawesi Utara, Gng. Ambang E.R., nr. Kotamobagu, Gng. Muajat summit area, ca 1780 m, Malaise trap, June 1985 (BMNH). Paratypes: the same data, $2 \succsim \mathrm{BMNH}, 10$ (LMBC).

Biology. Specimens were collected using Malaise traps.

Distribution. Indonesia: Sulawesi.

Ambangia wallacei sp. n.

(Figs 5, 17, 33-35, 72)

Diagnosis. Secondary costae reduced in distal half of elytra, phallus widest at base.

Description. Body dark brown, head with small eyes, interocular distance $1.4 \times$ longer than eye diameter. Antennae filiform, reaching two-fifths of elytral length. Mandibles arcuate, terminal palpomeres of maxillary and labial palpi apically pointed. Pronotum trapezoidal, transverse, widest at basal margin, posterior angles strongly sharp, lateral margins considerably arcuately emarginate. Pronotum with median longitudinal groove in basal half. Elytra slightly narrowed apically, $3.1 \times$ times longer than humeral width. Each elytron with nine costae in basal half, alternate costae weakly stronger, secondary costae abruptly interrupted in basal half, absent in posterior portion. Reticulate cells irregular. Abdominal sternum 9 emarginate distally (Fig. 72), distal emargination of tergum 9 short. Male genitalia with phallus widest basally (Figs 33-35). Body length: 2.1-2.6 mm, width at humeri: $0.5-0.7 \mathrm{~mm}$.

Etymology. Named in honour of A.R. Wallace.

Type material. Holotype, $\widehat{\delta}$, Indonesia, Sulawesi Utara, Gng. Ambang E.R., nr. Kotamobagu, Gng. Muajat summit area, ca 1780 m, Malaise trap, June 1985 (BMNH). Paratypes: same data, 4 0 (BMNH), $2 \sigma^{\star}$ (LMBC).

Biology. Four specimens were collected using Malaise traps, one specimen using yellow pan traps.

Distribution. Indonesia: Sulawesi.

Macroambangia subgen. $\mathbf{n}$.

(Figs 6-8, 15-16, 19, 36-43, 65-67)

Type species. Ambangia (Macroambangia) pallidicornis sp. $\mathrm{n}$.

Diagnosis. Antennomere 3 very small, as long as 2, phallus apically pointed.
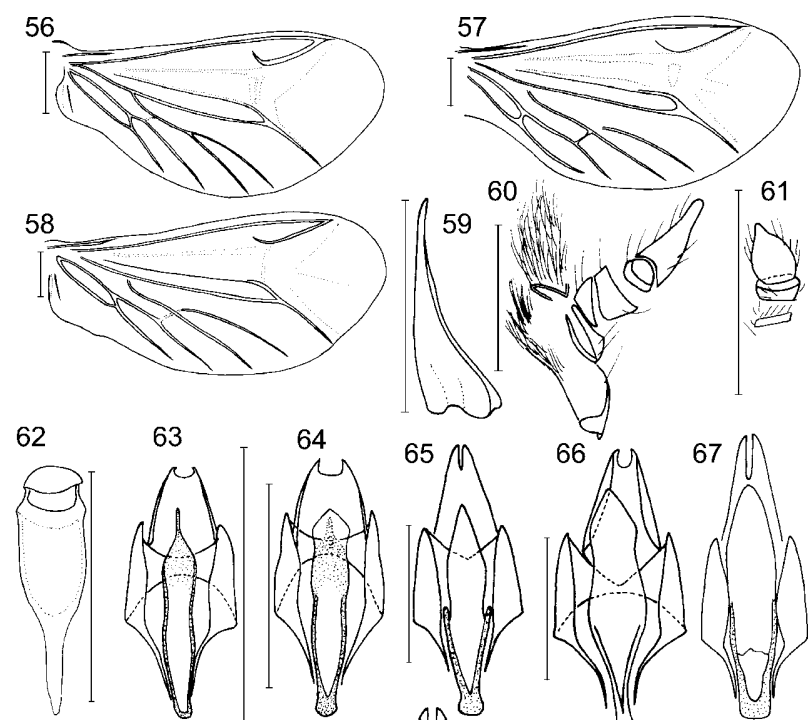

63
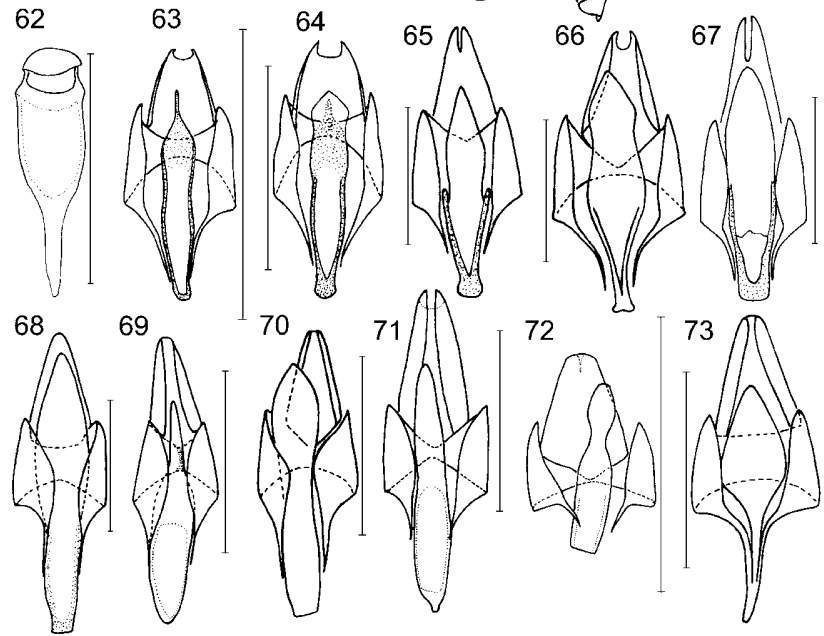

Figs 56-73: 56-58: Wing venation of: 56 - Lyrolib minor sp. n., 57 - Microlyropaeus dembickyi sp. n., 58 - Horakiella pahangana sp. n.; 59-62: mouthparts of Lyrolib grandis sp. n.: 59 - mandible, 60 - maxilla, 61 - labial palpus, 62 - labrum and hypopharynx; 63-73: male terminal abdominal segments: $63-$ Lyrolib minor sp. n., $64-$ L. grandis sp. n., 65 - Ambangia (Macroambangia) celebensis sp. n., 66 - A.(M.) pallidicornis sp. n., $67-A$. (M.) nigricornis sp. n., 68 - Horakiella hammondi sp. n., $69-H$. pahangana sp. n., $70-H$. emasensis sp. n., 71 - Ambangia nigra sp. n., $72-$ A. wallacei sp. n., $73-$ Microlyropaeus dembickyi sp. n. Scale $-0.5 \mathrm{~mm}$, scale for Figs 59-62: $0.25 \mathrm{~mm}$.

Description. Head with small eyes, antennae filiform, 11-segmented, antennomere 1 stout, 2 small, 3 cupshaped, as long as 2, 4-11 much longer than antennomere 1. Mandibles strongly curved apically, maxillary palpi 4-segmented, labial palpi reduced, terminal palpomeres of both palpi apically pointed. Pronotum transverse, trapezoidal, with longitudinal groove basally. Elytra elongate, provided with nine weak costae, alternate costae sometimes reduced to absent, reticulate cells irregular to absent. Mesosternum strongly transverse, wing venation with brace $\mathrm{CuA}_{1}$ absent. Terminal abdominal sternum laterally arcuately emarginate, terminal tergum with slender emargination distally. Legs slender, trochanters long, hind trochanters as long as half of sternal length, tibiae straight, their spurs small, acute, only tarsomere 4 lobed. Male genitalia with phallus apically pointed, paramerae tapering to apex.

Etymology. Name created using the Greek prefix Macromeaning large (makros) and the generic name Ambangia.

Distribution. Indonesia: Sulawesi. 
Ambangia (Macroambangia) pallidicornis sp. $\mathbf{n}$.

(Figs 6, 15, 36-37, 66)

Diagnosis. Black, only terminal antennomere yellow, phallus widest basally.

Description. Body dark brown, terminal antennomere yellow. Head with small eyes, interocular distance $1.6 \times$ longer than eye diameter. Antennae filiform, reaching two-fifths of elytral length. Pronotum transverse, trapezoidal, widest at basal margin, anterior margin slightly produced anteriorly, lateral margins simply arcuately emarginate. Scutellum oblong, triangular apical emargination reaching $1 / 4$ of its length. Elytra elongate, slightly widened distally, about $3.5 \times$ longer than humeral width. Each elytron with four complete longitudinal costae, alternate costae abruptly interrupted, almost invisible, reticulate cells irregular, almost missing. Mesosternum transverse, legs slender, strongly compressed, trochanters long, as long as half of femur. Male genitalia with phallus widest basally, paramerae long, as long as $7 / 8$ of aedeagal length. Body length: $5.6-6.2 \mathrm{~mm}$, width at humeri: $1.4-1.6 \mathrm{~mm}$.

Etymology. Named in reference to pale colouration of terminal antennomere.

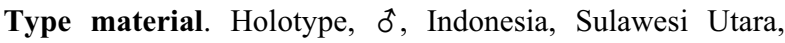
Dumoga Bone N.P., iv.-v.1985 (BMNH). Paratypes: the same data, 20 (BMNH), $2 \sigma^{\star}$ (LMBC); Gng. Ambang E.R., nr. Kotamobagu, lower montane forest, $1300 \mathrm{~m}$, Malaise trap, 2.-18.v.1985, 3 ơ (BMNH).

Biology. Collected in Malaise trap.

Distribution. Indonesia: Sulawesi.

Ambangia (Macroambangia) celebensis sp. $\mathbf{n}$.

(Figs 7, 16, 38-40, 65)

Diagnosis. Male genitalia with paramerae very slender in distal half.

Description. Body dark brown, only terminal antennomeres 10 and 11 lighter, 11 almost yellow. Head with small eyes, interocular distance $1.5 \times$ longer than eye diameter, antennae filiform, reaching elytral midlength. Pronotum trapezoidal, transverse, widest at basal margin, anterior margin weakly produced forwards, lateral margins almost straight, convergent anteriorly. Scutellum with a shallow arcuate apical notch. Elytra elongate, subparallel-sided, 3.3× longer than humeral width. Each elytron with nine longitudinal costae, alternate costae stronger, costae 1, 2, and 3 diminishing in posterior half, reticulate cells irregular. Male sternum 9 with stout lateral margins in basal half. Legs slender, trochanters long, as long as half of femur, tibiae straight, their spurs small, slender and acute, tarsomere 4 lobed. Male genitalia with phallus slender basally, paramerae broad in basal half, strongly narrowed medially, terminal half of paramerae very slender. Body length: $4.5-5.0 \mathrm{~mm}$, width at humeri: $1.2-1.3 \mathrm{~mm}$.

Etymology. Named in reference to the range of distribution.

Type material. Holotype, $\hat{\sigma}$, Indonesia, Sulawesi Utara, Dumoga Bone N.P., November 1985, ca 200 m, lowland forest (BMNH). Paratypes: same data, v.-xii.1985, 30 (BMNH), 10 (LMBC).
Biology. Specimens were collected using Malaise traps (4) and flight interception traps (1).

Distribution. Indonesia: Sulawesi.

\section{Ambangia (Macroambangia) nigricornis sp. $\mathbf{n}$.}

(Figs 8, 19, 41-43, 67)

Diagnosis. Antennae entirely black, lateral margins of pronotum deflected medially, phallus slender.

Description. Whole body black, head with small eyes, interocular distance $1.7 \times$ longer than eye diameter. Antennae filiform, reaching elytral midlength. Mandibles arcuate in apical portion. Pronotum trapezoidal, transverse, lateral margins parallel in basal half, strongly convergent anteriorly. Scutellum oblong, weakly triangularly emarginate apically. Elytra elongate, slightly widened backwards, 3.6× longer than humeral width. Each elytron with nine longitudinal costae, alternate costae $(2,4,6,8)$ stronger, reticulate cells irregular but conspicuous. Male genitalia with long phallus, paramerae as long as $3 / 4$ of phallus length. Body length: 5.7-6.0 mm, width at humeri: $1.4-1.5 \mathrm{~mm}$.

Etymology. Named in reference to the colouration of antennae.

Type material. Holotype, $\widehat{\delta}$, Indonesia, Sulawesi Utara, Gng. Ambang E.R., nr. Kotamobagu, Gng Muajat summit area, ca 1780 m, Malaise trap, June 1985 (BMNH). Paratypes: same data, 11 ๙ิ (BMNH), 4ð๋ (LMBC).

Biology. Most specimens were collected in Malaise traps, two specimens in yellow pan traps.

Distribution. Indonesia: Sulawesi.

\section{Genus Horakiella gen. $n$.}

(Figs 10, 12-14, 20, 45-53, 58, 68-70)

Type species. Horakiella pahangana sp. $\mathrm{n}$.

Diagnosis. Horakiella differs from Pendola Bocák in having a phallus rounded distally, and from Ambangia in having the base of phallus emarginate dorsally.

Description. Head with small eyes, interocular distance much longer than eye diameter, antennae filiform, reaching over elytral midlength. Antennomere 2 and 3 short, mandibles arcuate, labrum small, semicircular, slightly longer than wide, bearing long setae. Maxillary palpi 4-segmented, terminal palpomeres of maxillary and labial palpi apically pointed. Pronotum trapezoidal, transverse, widest at basal margin, posterior angles acute, lateral margins emarginate. Pronotum with median longitudinal groove in posterior half. Scutellum strongly emarginate apically, almost bilobed. Elytra elongate, subparallel-sided, each elytron with nine weak longitudinal costae, costae sometimes interrupted, even missing. Reticulate cells irregular, intercostal intervals sometimes only rugose. Mesosternum trapezoidal, transverse. Wing venation with brace $\mathrm{CuA}_{1}$ almost invisible, trace of $\mathrm{CuA}$ in place of bifurcation of $\mathrm{MP}_{3+4}$. Male sternum 9 elongate, with stout margins in proximal portion. Legs slender, compressed, hind trochanters as long as half of femur, tibiae straight, their spurs small, slender, acute, tarsomere 4 lobed. Male genitalia with phallus rounded distally, 
phallus with bulb-shaped enlargement basally, dorsally emarginate at base. Paramerae slender, reaching distal sixth of phallus. Body length: $3.6-5.4 \mathrm{~mm}$, width at humeri: $0.9-1.4 \mathrm{~mm}$.

Etymology. Named in honour of the collector of the type species - J. Horák from Prague. The gender is feminine.

Distribution. Peninsular Malaysia, Borneo.

\section{Horakiella pahangana sp. $\mathbf{n}$.}

(Figs 11, 14, 45-47, 58, 69)

Diagnosis. Whole body black, only antennomeres 10 and 11 yellow.

Description. Whole body black, only antennomeres 10 and 11 yellow. Head with small eyes, interocular distance $1.7 \times$ longer than eye diameter. Antennae filiform, reaching apical three-fifths of elytral length, antennomere 3 slightly shorter than 2 (Fig. 14). Pronotum with median longitudinal groove, lateral margins simply arcuately emarginate. Scutellum bilobed, distal emargination narrow, as long as half of its length. Elytra elongate, about $3.5 \times$ longer than humeral width. Each elytron with nine longitudinal costae almost equally strong, costae disjointed posteriorly. Elytra pubescent, with erect pubescence. Male sternum 9 elongate, slender. Body length: $4.0-4.2 \mathrm{~mm}$, width at humeri: $0.9-1.0 \mathrm{~mm}$.

Etymology. Named in reference to locality datum.

Type material. Holotype, $\widehat{\delta}$, Malaysia: Pahang, Cameron Highlands, Tanah Rata, 1600 m, 11.-27.ii.2000, J. Horák lgt. (LMBC). Paratypes: the same data, 20 (LMBC); the same data, P. Pacholátko lgt., 1 ơ (LMBC).

Distribution. Malaysia.

Remark. Holotype will be deposited at NMPC.

\section{Horakiella hammondi sp. $\mathrm{n}$.}

(Figs 10, 13, 51-53, 68)

Diagnosis. Horakiella hammondi sp. n. differs from $H$. pahangana sp. $\mathrm{n}$. in having yellow humeral portions of elytra, and in the shape of phallus having ventral emargination in basal sixth

Description. Body dark brown, only elytra with large yellow humeral spots, as long as third of elytral length at sides, but almost whole suture dark brown. Head with small eyes, interocular distance $1.6 \times$ longer than eye diameter. Antennae reaching elytral midlength, antennomere 3 slightly longer than 2 (Fig. 13). Pronotum with a median pair of oblique folds besides oblique basal folds. Scutellum dark brown, widely bilobed in distal half. Elytra parallel-sided, $3.5 \times$ longer than humeral width. Each elytron with nine slight costae of equal strength, reticulate cells almost absent, reduced to two rows of shallow punctures. Abdominal sternum 9 elongate, terminal tergum without apical emargination. Male genitalia slender with phallus emarginate ventrally in basal sixth. Body length: 5.2-5.4 mm, width at humeri: $1.2-1.4 \mathrm{~mm}$.

Etymology. Named in honour of the collector.

Type material. Holotype, $\hat{\jmath}$, Sarawak, Gn. Mulu N.P., UMR forest, above 1700 m, ii.-v.1978, I. Hanski leg., (BMNH). Paratypes, Sarawak, Gn. Mulu N.P., nr. Camp, 1800 m, v.-viii.1978, P.M. Hammond \& J.E. Marshall leg., 2 o (BMNH, LMBC).
Biology. Two specimens collected in pitfall traps, fish bait, one specimen collected by general sweeping.

Distribution. Malaysia: Sarawak.

Horakiella emasensis sp. $\mathbf{n}$.

(Figs 12, 20, 48-50, 70)

Diagnosis. Horakiella emasensis sp. n. differs from other known Horakiella species in having basal half of elytra yellow, and in the shape of male genitalia with paramerae as long as half of phallus.

Description. Body dark brown, only basal half of elytra yellow. Head with small eyes, interocular distance 1.6× longer than eye diameter. Antennae reaching elytral midlength, antennomere 3 longer than 2 (Fig. 20). Pronotum trapezoidal, anterior angles sharp, basal and lateral margins bisinuate. Scutellum widely triangularly bilobed, with lateral margins weakly convex, posterior tips sharp. Elytra parallel-sided, 3.4× longer than humeral width. Longitudinal costae almost absent, elytra glabrous in basal half, punctured posteriorly, reticulate cells absent. Abdominal sternum 9 elongate, terminal tergum without apical emargination. Male genitalia slender, with phallus not emarginate ventrally, paramerae shortened, as long as half of phallus.

Body length: $3.6 \mathrm{~mm}$, width at humeri: $1.0 \mathrm{~mm}$.

Etymology. Named in reference to type locality.

Type material. Holotype, đ, Borneo, Sabah, km 53 KKTambunan, $1650 \mathrm{~m}$, Gn. Emas, 22.iii-6.iv.2000, Bolm lgt. (LMBC).

Distribution. Malaysia: Sabah.

Remark. Holotype will be deposited at NMPC.

Genus Alyculus Kazantsev, 1999

Alyculus Kazantsev, 1999: 252, type species: Alyculus kurbatovi Kazantsev, 1999 (by monotypy).

Diagnosis. Brachyelyetrous, head with small eyes, antennae filiform, 11-segmented, mouthparts reduced. Pronotum without carinae, scutellum bilobed apically. Elytra as long as $2 / 5$ of body length, densely punctured. Male genitalia with straightened paramerae in distal portion.

Distribution. Indonesia: Java, Sumatra.

\section{Alyculus wittmeri sp. n.}

(Figs 3, 24, 54-55)

Diagnosis. It differs from $A$. kurbatovi in having the whole body light brown, and in male genitalia with paramerae widest in quarter of their length, while $A$. kurbatovi body colouration is dark brown to black, and lateral margins of paramerae parallel in basal half.

Description. Whole body light brown, head with large eyes, interocular distance as long as eye diameter. Antennae filiform, antennomere 1 long, 2 small, 3 weakly longer than 1. Mouthparts with mandibles reduced, labrum minute, maxillary palpi 4-segmented, apically pointed. Pronotum transverse, widest at basal margin, anterior margin straight, lateral margins strongly emarginate, posterior margin bisinuate. Pronotum without carinae. Scutellum bilobed apically, distal tips projected 
obliquely backwards. Elytra shortened, tapering to apex, distal portion rounded. Elytra densely punctured, with no trace of costae or reticulate cells. Abdominal sternum 8 simple, 9 elongate. Legs slender, tarsomere 4 lobed. Male genitalia (Fig. 54) with slender phallus widened basally, paramerae strengthened in distal half.

Body length: $1.1 \mathrm{~mm}$, humeral width: $0.3 \mathrm{~mm}$, length of elytra: $0.4 \mathrm{~mm}$.

Etymology. Named in honour of a notable student of cantharoid families, late W. Wittmer (Basel, Switzerland), through whose courtesy I received the specimen.

Type material. Holotype, $\delta^{\hat{\alpha}}$, Sumatra, Aceh prov., G. Leuser Nat. P., Ketambe, rainforest, 350 m, $3^{\circ} 41^{\prime} \mathrm{N}, 97^{\circ} 39^{\prime} \mathrm{E}$, D.C. Darling, Malaise TP. (LMBC).

Distribution. Indonesia: Sumatra.

Remark. Holotype will be deposited at NMPC.

\section{DISCUSSION}

The phylogenetic relationships within the tribe Lyropaeini are difficult to establish. Kazantsev (1998) proposed the genera Lybnopaeus and Lyroneces based on rather detailed characters for some species formerly classified within Lyropaeus.

Lybnopaeus and Lyroneces share many synapomorphies with Lyropaeus in restricted sense, and therefore the three genera form a clear clade. Although Lybnopaeus and Lyroneces display several autapomorphic features, it is not the case for Lyropaeus, which becomes paraphyletic after Lybnopaeus and Lyroneces species are excluded. The validity of the separate genera will be tested using molecular methods in the near future. Another distinct clade within Lyropaeini is formed by Antennolycus + Microlyropaeus and Ambangia + Horakiella which is supported by male genitalia characters. Pendola seems to be related to Lyropaeus + Lybnopaeus + Lyroneces clade, based on the shape of paramerae with toothed apex. Mutual relationships of these clades to Alyculus and Lyrolib are not clear and need further study using molecular methods.

The material collected during the Wallace Project of the Royal Entomological Society in Northern Sulawesi was sorted to six species by the staff of The Natural History Museum in London. After examination of male genitalia, one species was split in two, other species were sorted similarly, so that the total number of recognised species of collected Lyropaeini was seven. Most of the material was collected using various kinds of traps (Malaise traps, flight interception traps, and yellow pan traps).
ACKNOWLEDGEMENTS. I would like to thank the following entomologists and institutions that provided material for this study: M. Brendell and M. Kerley (The Natural History Museum, London), and T. Huflejt (Zoological Institute, Warszawa). This study has been supported by the grant 206/03/0982 from the Grant Agency of the Czech Republic.

\section{REFERENCES}

BocÁk L. 2002: Pendola, a new lycid genus (Coleoptera, Lycidae) from the Australian Region. Biologia 57: 557-561.

BocÁK L. \& BocáKovÁ M. 1989: New tribe Lyropaeini, with a description of a new species of Lyropaeus (Coleoptera, Lycidae). Pol. Pis. Entomol. 58: 717-723.

BocÁK L. \& Matsuda K. 2003: Review of the immature stages of the family Lycidae (Insecta: Coleoptera). J. Nat. Hist. 37: 1463-1507.

BocákovÁ M. 2001: Revision and phylogenetic analysis of the subfamily Platerodinae (Coleoptera, Lycidae). Eur. J. Entomol. 98: 53-85.

BocÁKovÁ M. 2004: Phylogenetic analysis of the tribe Libnetini and new genus Prolibnetis gen. n. (Coleoptera: Lycidae). Dt. Entomol. Z. 51: 53-64.

Bocáková M. \& Bocák L. 1999: New Lycidae from peninsular Malaysia (Coleoptera). Entomol. Basil. 21: 105-109.

Gravely F.H. 1915: The larvae and pupae of some beetles from Cochin. Rec. Indian Mus. 11: 353-366.

KaZANTSEV S. 1993: Lycidae nouveaux ou peu connus de l'Indochine (Coleoptera). Bull. Mus. Natl. Hist. Natur. Paris (Sec. A, 4) 15(1-4): 49-68.

KaZANTSEV S. 1998: Two new oriental genera of the tribe Lyropaeini (Coleoptera: Lycidae). Elytron 12: 15-22.

KaZANTSEv S. 1999: Alyculus, new genus, first brachypterous male lycid (Insecta: Coleoptera). Raffles Bull. Zool. 47: 251-255.

KleINe R. 1926: Die Lyciden der Philippinen-Inseln. Philipp. J. Sci. 1926: 33-114.

Knight W.J. 1988: Project Wallace Report. Royal Entomological Society, London, iii $+61 \mathrm{pp}$.

Kukalova-Peck J. \& Lawrence J.F. 1993: Evolution of hind wing in Coleoptera. Can. Entomol. 125: 181-258.

Medvedev L.N. \& Kazantsev S. 1992: A new subfamily and a new genus of lycid beetles (Coleoptera, Lycidae) from Southeast Asia. In Medvedev L.N. (ed.): Insect Systematics and Ecology of Vietnam. Nauka, Moscow, pp. 55-60.

MJöBERG E. 1925: The mystery of the so called "trilobite larvae" or "Perty's larvae" definitely solved. Psyche 32: 119-157.

PIC M. 1929: Coléoptères exotiques en partie nouveaux. L'Echange 435: 4.

WATERHOUSE C.O. 1878: On the different forms occurring in the coleopterous family Lycidae, with description of new genera and species. Trans. Entomol. Soc. London 1878: 95-118.

Received September 16, 2004; revised and accepted May 31, 2005 